UDC 658.147-048.445:001.82

DOI: 10.15673/fie.v11i2.1392

\author{
Markova T. \\ Ph.D., Associate Professor \\ Department of Accounting and Auditing \\ E-mail: markova.tetiana17@gmail.com \\ ORCID ID: 0000-0002-9437-2635 \\ Mytrofanov 0. \\ The student of the fourth grade of Econ- \\ omy, Business and Control Faculty \\ E-mail: mitsashaa@gmail.com
}

\author{
Volodina 0. \\ Assistant \\ Department of Foreign Languages \\ E-mail: completeness7@mail.ru
}

Chehlatonieva A.

The student of the second grade of Economy,

Business and Control Faculty Odessa National Academy of Food Technologies

Kanatna str., 112, Odesa, Ukraine, 65039

E-mail: chegla30@gmail.com

\title{
EQUITY CAPITAL: APPROACHES TO DEFINITION, CLASSIFICATION AND ITS STRUCTURE
}

The article examines the essence of the concept of "equity capital" and conceptual approaches to its definition and classification. It has been determined that the concept of "capital" has had roots since antiquity, and meant a source of accumulation of wealth. However, in today's conditions of the market system capital is generalizing and at the same time varied, because it covers intellectual, natural, social capital. The importance of the correct calculation of structural equilibrium, which is a guarantee of financial competitiveness, financial stability and solvency in modern fast financial, economic and legislative changes, has been substantiated. Three approaches to the classification of the structure of the enterprise according to the normativelegislative base (national and international) and practical aspect has been determined. The practical analytical analysis of the equity structure based on the financial statements of the enterprise indicates that the equity of the enterprise in the current conditions of management decreases, in particular, by increasing the uncovered loss. The advantage of debt capital in the form of payables proves the need to make optimal decisions on timely control and adjustment of the capital structure of the enterprise due to the dynamics and features of socio-economic and financial processes in Ukraine.

Key words: equity capital, structure, enterprise, classification.

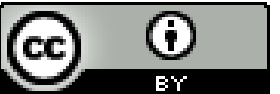

This work is licensed under a Creative Commons Attribution 4.0 International License http://creativecommons.org/licenses/by/4.0/
Statement of the problem and its connection with important scientific and practical tasks. Capital is the main component of the development of any business. Any capital oriented to a long-term economic success is complex, multifaceted, and therefore is not sufficiently investigated economic phenomenon and is characterised by the presence of diverse opinions of the conceptualcategorical apparatus of the definition of "capital". As a rule, the beginning of any business and entrepreneurial activity, both in ancient times and in the current conditions of a market economy, requires capital investment and depends on its structure. In particular, imbalance in the structure of capital is one of the important problems of the activity of any business entity and often leads to a decrease in the efficiency of its activities and a decrease in the values of financial and economic indicators. In addition, one of the main causes of the crisis situation in most Ukrainian businesses is the existence of an unclear capital management system, an incorrect definition and calculation of the ratio between equity and borrowed capital. And, therefore, for an enterprise it is very important to create tools for determining such a balance, timely and effective adaptation in the modern internal and external conditions.

The analysis of the latest publications on the problem. Analyzing the achievements of economic science, it can be argued that such prominent economists such as: Butinets F.F., Burkinsky B.V., Tkachenko N.M., Blank I.O., Balatsky O.F., Kakhovska OV, Makarova G.S., Valikov VP, Aref'eva O.V., Myagakhi I.M., Sopko V.V., Antonyuk O.P. have made a significant contribution to the study of the modern concept of "capital", formation and structuring of capital of enterprises. Without diminishing the contribution of domestic scholars in substantiating this problem, it should be noted that some aspects of the issue are still controversial and require further research and development.

Forming of the aims of the research. The purpose of this research is theoretical substantiation of the conceptual categorical apparatus "capital", its logical interconnection, interdependence and the balance of the structure.

Giving an account of the main results and their substantiation. In the theory of economics, as a rule, many interpretations of the concept of "capital of the enterprise" are given. Yushko S.V. and Lugova A. be- 
lieve that such a number of views on this concept is connected with "... the detachment of Ukrainian economic science from the processes that are taking place in our transition economy today. It also shows a certain lack of understanding of the laws of functioning of a market economy, which gradually replace the commandadministrative system, or not so successful attempt to combine the features of these two systems into one. Undoubtedly, this complicates the consideration of theoretical aspects of capital circulation and the practice of its formation in the conditions of adaptation of the Ukrainian economy to the market environment" [1]. It should be noted that in the investigated works, the authors distin- guish the functions of capital, its composition, influence on the formation of financial and economic indicators of the enterprise. The concept of "capital" was studied by representatives of various economic schools, from antiquity to modern times. Thus, the notion of "capital" was viewed initially as a source of wealth accumulation (Aristotle), and then as material assets directed at production with the aim of obtaining profit (classical economic school). It should be noted that the notion of "equity" is considered today in both contemporary economic literature (Table 1) and in the normative-legislative field (Table 2).

Table 1

The essence of the notion of "equity of the enterprise" by various contemporary scientists-economists*

\begin{tabular}{|c|c|}
\hline Authors, source & Definition of the essence \\
\hline F.F. Butinets & $\begin{array}{l}\text { Equity capital - a part of financial resources, cash, invested in entrepreneurial activities in } \\
\text { order to obtain profit. }\end{array}$ \\
\hline S.F. Golov & $\begin{array}{l}\text { The equity of the enterprise characterizes the total cost of funds in monetary, tangible and } \\
\text { intangible forms invested in the formation of its assets. }\end{array}$ \\
\hline $\begin{array}{l}\text { A.A. Gorbatenko, } \\
\text { L.V. Ivchenko }\end{array}$ & $\begin{array}{l}\text { Equity capital expresses the total amount of funds in monetary, material and non-material } \\
\text { forms, invested in assets (property) of the enterprise. }\end{array}$ \\
\hline N.M. Tkachenko & $\begin{array}{l}\text { Equity capital - are its own sources of financing of the enterprise, which, were made by } \\
\text { its founders (participants), or left by them at the enterprise from net profit without } \\
\text { determining the term of repayment. }\end{array}$ \\
\hline Ya.P. Ishchenko & $\begin{array}{l}\text { Equity capital is a necessary factor of production, it includes components of debt, } \\
\text { retained earnings, preferred shares and ordinary shares. }\end{array}$ \\
\hline L.I. Katan & $\begin{array}{l}\text { Equity capital is a definite expression of financial relations that arise between a joint- } \\
\text { stock company (corporation) and other economic entities in relation to its formation and } \\
\text { use. }\end{array}$ \\
\hline V.F. Maximova & $\begin{array}{l}\text { Equity capital is the sum of the valuation of property and funds of the entrepreneur, } \\
\text { which he can use for economic needs. }\end{array}$ \\
\hline A.M. Rumyantsev & Relationship of operation. \\
\hline $\begin{array}{l}\text { A.S. Bulatov, } \\
\text { K.A. Raitsky }\end{array}$ & Benefits, used as a resource in further production. \\
\hline A.V. Paramonov & Production means that bring added value. \\
\hline P. Burdier & $\begin{array}{l}\text { Resource, which is converted into money and institutionalized in the form of property } \\
\text { rights. }\end{array}$ \\
\hline I.O. Blank & $\begin{array}{l}\text { Accumulated stock of economic benefits in monetary and commodity form, taking part in } \\
\text { the economic process as an investment resource and factor of production. }\end{array}$ \\
\hline $\begin{array}{l}\text { N.A. Rusak } \\
\text { V.A. Rusak }\end{array}$ & $\begin{array}{l}\text { Capital is the funds invested in an entity to start or continue business in order to obtain a } \\
\text { profit (income). }\end{array}$ \\
\hline V.V. Seleznev & $\begin{array}{l}\text { Capital is the financial resources used to develop the production process (the purchase of } \\
\text { raw materials, goods and other objects, force, other elements of production), there is } \\
\text { capital in its monetary form. }\end{array}$ \\
\hline $\begin{array}{l}\text { S.V. Moiseev, } \\
\text { V.I. Terekhin }\end{array}$ & $\begin{array}{l}\text { Capital - is the financial means of the enterprise, reflected in the liability of its balance } \\
\text { sheet. }\end{array}$ \\
\hline V.G. Belolipetsk & $\begin{array}{l}\text { Capital as a part of the financial resources involved in the turnover, and the income that } \\
\text { they bring from this treatment. In this sense, capital serves as a transformed form of } \\
\text { financial resources. }\end{array}$ \\
\hline I.T. Balabanov & $\begin{array}{l}\text { Capital is a part of financial resources. Capital is the money put into circulation and the } \\
\text { income that they bring from this treatment. }\end{array}$ \\
\hline I. Fischer & Capital is any asset that generates income (value added). \\
\hline $\begin{array}{l}\text { L.V. Ivchenko } \\
\text { N.L. Udovik. }\end{array}$ & $\begin{array}{l}\text { Capital represents a set of material assets and funds, financial investments and expenses } \\
\text { for the acquisition of rights and privileges necessary for the implementation of its } \\
\text { economic activities. }\end{array}$ \\
\hline
\end{tabular}

\footnotetext{
* systematized by authors on the basis of sources [2-6]
} 
Table 2

Approaches of normative and legislative acts on the definition of the concept "equity capital"*

\begin{tabular}{|l|l|}
\hline \multicolumn{1}{|c|}{ Source } & \multicolumn{1}{c|}{ Definition of the essence } \\
\hline $\begin{array}{l}\text { Law of Ukraine "On Accounting and } \\
\text { Financial Reporting in Ukraine" }\end{array}$ & $\begin{array}{l}\text { Equity capital is the difference between assets and liabilities of an en- } \\
\text { terprise [7] }\end{array}$ \\
\hline $\begin{array}{l}\text { National Standards Accounting 1 "General } \\
\text { Requirements for Financial Statements" }\end{array}$ & $\begin{array}{l}\text { Equity capital is part of the assets of an enterprise remaining after } \\
\text { deducting its liabilities [8] }\end{array}$ \\
\hline $\begin{array}{l}\text { International Standard of Accounting 1 } \\
\text { "Presentation of Financial Statements" }\end{array}$ & Summarized quantitative data about the amount classified as equity [9] \\
\hline
\end{tabular}

* systematized by authors on the basis of sources [7-9]

It should be noted that the scientist V.D. Bazylevych distinguishes five approaches to the definition of the essence of "capital" [10]:

1. The object-functional approach identifies capital with accumulated labor, which is intended for the subsequent process of production or realization in order to obtain income.

2. Socio-economic approach treats capital as an economic category, consisting of interconnected special relations that arise under certain historical conditions.

3. Monetary approach examines capital as a financial investment that brings income to the owner in the form of interest.

4. The approach of the time concept of capital is to compare the values of present goods and the future at different times and the derivation of income from certain properties of the latter.

5. The treatment of capital as a kind of investment indicates that capital provides income to the owner from any kind of economic activity.

We should note that scientists Burkinsky B.V. and Goryachuk V.F. investigate capital in various aspects, including human, social, natural and intellectual [11, c. 42]. Consequently, the concept of "capital" is rather broad and therefore we are paying attention to the notion of "equity of the enterprise".
According to accounting, the capital of an enterprise is its resources (the left part of the balance sheet), accumulated by investing own and borrowed capital (the right side of the balance sheet).

Thus, summing up the various interpretations of the concept of "capital" and "equity", we can note that, from our point of view, the equity of an enterprise is that part of the resources of a business entity that is invested in the process of business and generates profits which then subject to refinancing.

It should be noted that controversial issue is the determination of the best balance between own and borrowed capital, which ensures the most effective proportion between the profitability and financial sustainability of the enterprise. In the broadest sense, the concept of "capital structure" means the ratio of own and borrowed funds, through which the enterprise carries out its economic activities. However, we note that the concepts of both own and borrowed capital have divergent economic content (Table 3 ). In the scientific world-wide sources of practical aspects there are different approaches to the classification of capital. And one of the most widespread is the classification of capital, proposed by the domestic scientist I.O. Blank It should be noted that in our study the structure of "equity" is considered as a component of the capital of the enterprise as a whole.

Table 3

Approaches of scientists regarding the essence of the concept of "capital structure"*

\begin{tabular}{|l|l|}
\hline \multicolumn{1}{|c|}{ Author, Source } & \multicolumn{1}{c|}{ Definition of the essence } \\
\hline I.O. Blank & $\begin{array}{l}\text { The capital structure is the ratio of all forms of own and borrowed funds used by the enterprise } \\
\text { in the process of economic activity to finance assets }\end{array}$ \\
\hline $\begin{array}{l}\text { V.N. Sutornina, } \\
\text { V.M. Fedosov }\end{array}$ & $\begin{array}{l}\text { The capital structure is considered as the ratio between the main sources during the formation } \\
\text { of funds. }\end{array}$ \\
\hline $\begin{array}{l}\text { N.A. Rusak, } \\
\text { V.A. Rusak }\end{array}$ & Capital structure - is the proportion of individual elements of capital in its total amount. \\
\hline A. Afanasyev & $\begin{array}{l}\text { Capital structure is a form or component of capitalization that belongs to the type and } \\
\text { proportions of securities used to increase financial resources }\end{array}$ \\
\hline S.F. Golov & $\begin{array}{l}\text { Equity capital is formed by two components: investing (shareholder investments) and } \\
\text { accumulated (retained earnings) of shareholders }\end{array}$ \\
\hline O.V. Yefimov & $\begin{array}{l}\text { In the structure of equity capital, two main components can be distinguished: } \\
\text { the invested capital, that is, the capital invested by the owners in the organization, and the } \\
\text { accumulated capital, that is, capital created over the one initially advanced by the owners }\end{array}$ \\
\hline
\end{tabular}

* systematized by authors on the basis of sources [12]

Equity capital, in accordance with ISA 1, is considered as a prepayable financial instrument and is divided into different classes such as paid-in capital, capi- tal surplus and capital reserves. In addition, for example, equity in a joint-stock company has the following subclasses: funds made by shareholders; undivided profit; 
reserves that reflect the allocation of retained earnings; reserves that reflect the adjustment of the retained capital [13, c. 286]. It should be noted that such a detailed classification is necessary for the adoption of management decisions by users of financial statements, in particular, parties with the same share of the invested resources in the enterprise.

Capital structure is a concept used in modern financial and economic analysis to reflect the ratio of the sources of loan and own investment, which is adopted in the enterprise to fulfill its market strategic goal.

According to the scientists, Valikov VP, Bondar VP, Bazileva KV, Kurinna IG the use by the entity of its own financial resources is due to their structuring in a certain way, or, in other words, the company must have a clear definition of the capital structure, according to which the decisions on its optimization will be made. [14].

Investigating the structure of equity, we have identified the following approaches to its classification:

1. Theoretical approach: the capital of an enterprise is divided into own and borrowed.
2. Equity capital is divided into subclasses depending on the form of ownership of the enterprise (in accordance with the Conceptual Framework of ISA).

3. According to NSA 1 "General Requirements to Financial Statements" (Appendix 1), equity is classified as: Registered (share) capital; contributions to unregistered authorized capital; capital in surplus valuations; additional capital; emission income; accumulated exchange rate differences; Reserve capital; retained earnings (uncovered losses); unpaid capital; withdrawn capital.

It should be noted that the analysis of the structure of capital plays an important role in the complex assessment of the financial condition of the enterprise, in particular its financial stability, because due to the analysis of liabilities it is possible to find out such important indicators of the financial state of the enterprise as: level of autonomy, level of financial risks, return on capital, etc. Thus, the analysis of composition, structure and dynamics of the enterprise's own capital in Table 4 is calculated on the basis of the practical approach of the classification of equity, systematized by the authors [15].

Table 4

Analysis of composition, structure and dynamics of equity capital of enterprises*

\begin{tabular}{|c|c|c|c|c|c|}
\hline \multirow{2}{*}{ Indices } & \multirow{2}{*}{$\begin{array}{l}\text { Line } \\
\text { code }\end{array}$} & \multirow{2}{*}{$\begin{array}{l}\text { The previous } \\
\text { year }\end{array}$} & \multirow{2}{*}{$\begin{array}{l}\text { Reporting } \\
\text { year }\end{array}$} & \multicolumn{2}{|c|}{ Deviation } \\
\hline & & & & absolute & $\%$ \\
\hline $\begin{array}{l}\text { Total equity, thousand UAH. } \\
\text { including: }\end{array}$ & 1495 & 9563 & 2519 & -7044 & $-73,7$ \\
\hline \multirow{2}{*}{$\begin{array}{l}\text { 1. Registered (share) capital, thousand } \\
\text { UAH. } \\
\quad \text { - in } \% \text { to equity capital }\end{array}$} & \multirow[t]{2}{*}{1400} & 10893 & 10893 & 0 & 0 \\
\hline & & 113,9 & 432,4 & 318,5 & $\mathrm{x}$ \\
\hline \multirow{2}{*}{$\begin{array}{l}\text { 2. Capital in surplus, thousand UAH. } \\
\text { - in\% to equity capital }\end{array}$} & \multirow{2}{*}{1405} & - & - & - & - \\
\hline & & - & - & - & $\mathrm{x}$ \\
\hline \multirow{2}{*}{$\begin{array}{l}\text { 3. Additional capital, thousand UAH. } \\
\text { - in } \% \text { to equity capital }\end{array}$} & \multirow[t]{2}{*}{1410} & 62916 & 62916 & 0 & - \\
\hline & & 657,9 & 2497,7 & 1839,7 & $\mathrm{x}$ \\
\hline \multirow{2}{*}{$\begin{array}{l}\text { 4. Reserve capital, thousand UAH.. } \\
\text { - in\% to equity capital }\end{array}$} & \multirow{2}{*}{1415} & 6239 & 6239 & 0 & - \\
\hline & & 65,2 & 247,7 & 182,4 & $\mathrm{x}$ \\
\hline \multirow{2}{*}{$\begin{array}{l}\text { 6. Undivided profit } \\
\text { (uncovered damage), thousand UAH. } \\
\text { - in } \% \text { to equity capital }\end{array}$} & \multirow{2}{*}{1420} & -70485 & -777529 & -7044 & 10,0 \\
\hline & & $-737,1$ & $-3077,8$ & $-2340,7$ & $\mathrm{x}$ \\
\hline \multirow{2}{*}{$\begin{array}{l}\text { 7. Unpaid capital, thousand UAH. } \\
\text { - in } \% \text { to equity capital }\end{array}$} & \multirow{2}{*}{1425} & - & - & - & - \\
\hline & & - & - & - & $\mathrm{x}$ \\
\hline \multirow{2}{*}{$\begin{array}{l}\text { 8. Capital withdrawn, thousand UAH. } \\
\text { - in } \% \text { to equity capital }\end{array}$} & \multirow{2}{*}{1430} & - & - & - & - \\
\hline & & - & - & - & $\mathrm{x}$ \\
\hline
\end{tabular}

* calculated by the authors on the basis of financial statements

From table 4 it is evident that the company's own capital in the reported year, in comparison with the previous year, decreased by UAH 7044 thousand, or by $73.7 \%$. This was due to an increase in uncovered damage by UAH 7044 thousand, or by $10.0 \%$; the value of registered (share) and additional capital remained unchanged.

Equity capital in the previous year was formed due to additional capital $(657.9 \%)$, registered capital (113.9\%), reserve capital (65.2\%), uncovered loss $(737.1 \%)$. In the reporting year, the following changes occurred in the structure of equity: the share of additional capital increased by $1839.7 \%$, registered capital by $318.5 \%$, reserve capital by $182.4 \%$, and a decrease in the share of uncovered losses by $2340.7 \%$.

Conclusions and prospects of the further investigations. As a result of the research of the conceptual-categorical apparatus "equity" it has been determined that this concept has a broad meaning. So today the essence of "capital" means not only the category of money, but also human, natural, social capital, as well as intangible assets. Thus, summing up the various interpretations of the notion of "equity capital " from the ancient times to the current market conditions, we have proposed the definition that the equity of an enterprise is that part of the resources of the business entity that is invested in the process of business and which brings profit, which then is subject to refinancing. 
The study of the equity structure made it possible to distinguish three approaches to its classification: the theoretical approach, in accordance with the Conceptual Framework of the ISA and in accordance with NSA 1 "General Requirements for Financial Reporting". The practical and analytical analysis of the structure of equity based on the financial statements of the enterprise indicates that the company's equity in the current conditions of management decreases, in particular, by increasing the uncovered loss. Thus, borrowed capital in the form of accounts payable prevails. Consequently, the dynamics and peculiarities of socio-economic and financial processes in Ukraine leave urgent questions to the enterprises of the country concerning optimization of capital structure management and making optimal decisions on timely control and adjustment of the capital structure of the enterprise.

\section{References}

1. Yushko, S. V., \& Luhova, A. (2011). Krytychnyi analiz ekonomichnoi sutnosti poniattia «kapital pidpryiemstva». Visnyk Ekonomiky Transportu I Promyslovosti, (36), 234-238.

2. Aref'ieva, O. V., Miahkykh, I. M., \& Rosumaka, T. H. (2016). Vlasnyi kapital pidpryiemstva ta problemy yoho formuvannia. Intelekt XXI, (6), 161-169.

3. Ivchenko, L. V. (2016). Vlasnyi kapital: Suchasnyi pohliad na yoho sutnist ta skladovi. Molodyi Vchenyi, (3), 79-83.

4. Tkachenko, N. M. (2006). Bukhhalterskyi finansovyi oblik, opodatkuvannia i zvitnist. Kyiv: Alerta.

5. Horodnia, T. A., \& Saviv, M. R. (2013). Diahnostyka kapitalu pidpryiemstva. Naukovyi Visnyk NLTU Ukrainy, (23.10), 185-190.

6. Ivchenko, L. V., \& Udovyk, N. L. (2016). Vlasnyi kapital: Dzherela formuvannia ta funktsii. Molodyi Vchenyi, (1 (1)), 55-59.

7. Pro bukhhalterskyi oblik ta finansovu zvitnist v Ukraini: Zakon Ukrainy vid 16.07.99 r. №996-KhIV za stanom na 16.11.2018 r. (2018). Retrieved April 07, 2019, from https://zakon.rada.gov.ua/laws/show/996-14

8. Zahalni vymohy do finansovoi zvitnosti: Natsionalne polozhennia (standart) bukhhalterskoho obliku №1: Zatv. nakazom Minfinu vid 07.02.2013 r. № 73 za stanom na 20.06.2018 r. (2018). Retrieved April 07, 2019, from https://zakon.rada.gov.ua/laws/show/z0336-13

9. Podannia finansovoi zvitnosti: Mizhnarodnyi standart bukhhalterskoho obliku № 1. (2012). Retrieved April 07, 2019, from https://zakon.rada.gov.ua/laws/show/929_013

10. Bazylevych, V. D. (Ed.). (2008). Ekonomichna teoriia: Politekonomiia (7th ed.). Kyiv: Znannia-Pres. IPREED NANU.

11. Burkynskyi, B. V., \& Horiachuk, V. F. (2014). Kapitalizatsiia ekonomiky rehioniv Ukrainy. Odesa:

12. Korkushko, O. N. (2013). Klasyfikatsiini vydy vlasnoho kapitalu, yak ob'iekta obliku. Stalyi Rozvytok Ekonomiky, (4), 262-265. «Ruta».

13. Butynets, F. F., \& Horetska, L. L. (2002). Bukhhalterskyi oblik u zarubizhnykh krainakh. Zhytomyr: PP

14. Valikov, V. P. (2017). Protses optymizatsii struktury kapitalu promyslovoho pidpryiemstva. Visnyk Pryazovskoho Derzhavnoho Tekhnichnoho Universytetu, (33), ekonomichni nauky, 225-234.

15. Antoniuk, O. P., Stupnytska, T. M., \& Kuprina, N. M. (2015). Ekonomichnyi analiz. Lviv: Mahnoliia 2006.

Received 12 April 2019

Approved 26 April 2019

Available in Internet 5.07.2019

Маркова Т.Д.

кандидат экономических наук, доцент кафедра учета и аудита

E-mail: markova.tetiana17@gmail.com ORCID ID: 0000-0002-9437-2635

Митрофранов А.C.

студент 4 курса факультета экономики, бизнеса и контроля

E-mail: mitsashaa@gmail.com

\section{Володина Е.П.} ассистент кафедра иностранных языков E-mail: completeness7@mail.ru

Чеглатонева А.C.

студентка 2 курса фракультета экономики, бизнеса и контроля

Одесская национальная академия пищевых технологий ул. Канатная, 112, г. Одесса, Украина, 65039

E-mail: chegla30@gmail.com

\section{СОБСТВЕННЫЙ КАПИТАЛ: ПОДХОДЫ К ОПРЕДЕЛЕНИЮ, КЛАССИФИКАЦИИ И ЕГО СТРУКТУРА}

В статье рассматривается сущность понятия «собственный капитал» и концептуальные подходы к его определению и классификации. Определено, что понятие «капитал» имеет корни со вре- 
мен античности, и означало источник накопления богатства. Однако, в современных условиях рыночной системы «капитал» является обобщающим и одновременно многообразным, ведь охватывает интеллектуальный, природный, социальный капитал. На основании обобщения различных толкований понятия «капитал» различными авторами и источниками, дано определение «собственный капитал предприятия». Обоснована важность правильного расчета структурной сбалансированности, которая является залогом финансовой конкурентоспособности, фринансовой устойчивости и платежеспособности в современных быстрых финансово-экономических и законодательных изменений. Определены три подхода к классификации структуры предприятия в соответствии с нормативно-законодательной базой (национальной и международной) и практическими аспектами. Рассматриваются теоретические и практические структурные учетные аспекты. Определено, что в теоретическом аспекте капитал рассматривается как совокупность собственного и заемного. Тогда как в практическом аспекте (согласно учетно-статистических документов) капитал классифицируется на различные его виды. Именно такая детализация позволяет вести аналитический учет и быть гибким к внутрихозяйственным изменениям на предприятии. Проведенный практически-аналитический анализ структуры собственного капитала на основании данных финансовой отчетности предприятия свидетельствует о том, что собственный капитал предприятия в современных условиях хозяйствования уменьшается, в частности, за счет увеличения непокрытого убытка. Преимущество заемного капитала в форме кредиторской задолженности свидетельствует о необходимости принятия оптимальных решений по своевременному контролю и корректировке структуры капитала предприятия, по влиянию динамики и особенностей социально-экономических и финансовых процессов в Украине.

Ключевые слова: собственный капитал, структура, предприятие, классификация.

\author{
Маркова Т.Д. \\ кандидат економічних наук, доцент \\ кафредра обліку та аудиту \\ E-mail: markova.tetiana17@gmail.com \\ ORCID ID: 0000-0002-9437-2635 \\ Митрофанов О.С. \\ студент 4 курсу факультету економіки, \\ бізнесу і контролю \\ E-mail: mitsashaa@gmail.com
}

\author{
Володіна О.П. \\ асистент \\ кафедра іноземних мов \\ E-mail: completeness7@mail.ru
}

Чеглатонєва А.C.

студентка 2 курсу факультету економіки, бізнесу і контролю

Одеська національна академія харчових технологій вул. Канатна, 112, м. Одеса, Україна, 65039

E-mail: chegla30@gmail.com

\section{ВЛАСНИЙ КАПІТАЛ: ПІДХОДИ ДО ЙОГО ВИЗНАЧЕННЯ, КЛАСИФІКАЦІЇ ТА ЙОГО СТРУКТУРА}

У статті розглядається сутність поняття «власний капітал» та концептуальні підходи до його визначення та класифікації. Визначено, що поняття «капітал» має коріння з часів античності, і означало джерело нагромадження багатства. Проте, в сучасних умовах ринкової системи «капітал» $€$ узагальнюючим й водночас різновидним, адже охоплює інтелектуальний, природний, соціальний капітал. На підставі узагальнення різних тлумачень поняття «капітал» різними авторами та джерелами, надано визначення «власний капітал підприємства». Обґрунтовано важливість правильного розрахунку структурної збалансованості, яка є запорука фрінансової конкурентоспроможності, фрінансової стійкості та платоспроможності в сучасних швидких фрінансово-економічних та законодавчих змін. Визначено три підходи до класифікації структури підприємства відповідно до нормативно-законодавчої бази (національної та міжнародної) та практичного аспекту. Розглядається теоретичні та практичні структурні облікові аспекти. Визначено, що в теоретичному аспекті капітал розглядається як сукупність власного та позикового. Тоді як в практичному аспекті (згідно обліково-статистичних документів) капітал класифікується на різні його види. Саме така деталізація дозволяє вести аналітичний облік та бути гнучким до внутрішньогосподарських змін на підприємстві. Проведений практично-аналітичний аналіз структури власного капіталу на підставі даних фінансової звітності підприємства свідчить про те, що власний капітал підприємства в сучасних умовах господарювання зменшується, зокрема, за рахунок збільшення непокритого збитку. Перевага позикового капіталу у формі кредиторської заборгованості свідчить про необхідність прийняття оптимальних рішень щодо своєчасного контролю та корегування структури капіталу підприємства за впливом динаміки та особливостей соціально-економічних та фрінансових процесів в Україні.

Ключові слова: власний капітал, структура, підприємство, класифікація. 


\section{Література}

1. Юшко С.В., Лугова А. Критичний аналіз економічної сутності поняття «капітал підприємства» // Вісник економіки транспорту і промисловості. 2011. № 36. С. 234-238.

2. Ареф'єва О.В., Мягких І.М., Росумака Т.Г. Власний капітал підприємства та проблеми його формування // Інтелект XXI. 2016. № 6. С. 161-169.

3. Івченко Л.В. Власний капітал: сучасний погляд на його сутність та складові // Молодий вчений. 2016. № 3. C. 79-83.

4. Ткаченко Н.М. Бухгалтерський фінансовий облік, оподаткування і звітність: Підручник. К.: Алерта, 2006. $1080 \mathrm{c}$.

5. Городня Т.А., Савів М.Р. Діагностика капіталу підприємства // Науковий вісник НЛТУ України. 2013. Вип. 23.10. С. 185-190.

6. Івченко Л.В., Удовик Н.Л. Власний капітал: джерела формування та функції // Молодий вчений. 2016. № 1(1). C. 55-59.

7. Про бухгалтерський облік та фінансову звітність в Україні: Закон України від 16.07.99 p. №996-XIV за станом на 16.11.2018 p. / Верховна Рада України. Київ. URL: https://zakon.rada.gov.ua/laws/show/996-14 (дата звернення: 07.04.2019).

8. Загальні вимоги до фінансової звітності: Національне положення (стандарт) бухгалтерського обліку №1: затв. наказом Мінфіну від 07.02 .2013 p. № 73 за станом на 20.06.2018 p. URL: https://zakon.rada.gov.ua/laws/show/z0336-13 (дата звернення: 07.04.2019).

9. Подання фінансової звітності: Міжнародний стандарт бухгалтерського обліку № 1: URL: https://zakon.rada.gov.ua/laws/show/929_013 (дата звернення: 07.05.2019). 2008. $719 \mathrm{c}$

10. Економічна теорія: Політекономія: підручник / за ред. В. Д. Базилевича. 7-ме вид. К.: Знання-Прес.,

11. Буркинський Б.В., Горячук В.Ф. Капіталізація економіки регіонів України: монографія / Ін-т проблем ринку та екон.-екол. досліджень НАН України. Одеса: ІПРЕЕД НАНУ, 2014. 293 с.

12. Коркушко О.Н. Класифікаційні види власного капіталу, як об’єкта обліку // Сталий розвиток економіки. 2013. № 4. С. 262-265.

13. Бутинець Ф. Ф. Бухгалтерський облік у зарубіжних країнах / Ф. Ф. Бутинець, Л. Л. Горецька. Житомир : ПП «Рута», 2002. 544 с.

14. Валіков В.П., Бондар В.П., Базілева К.В., Курінна І.Г. Процес оптимізації структури капіталу промислового підприємства // Вісник Приазовського державного технічного університету. Серія : Економічні науки. 2017. Вип. 33. С. 225-234.

15. Антонюк О.П., Ступницька Т.М., Купріна Н.М. Економічний аналіз: навчальний посібник. Львів: Магнолія 2006, 2015. 326 с.

Стаття надійшла 12.04.2019

Стаття прийнята до друку 26.04.2019

Доступно в мережі Internet 5.07.2019

Цитування згідно ДСТУ 8302:2015

Markova T., Volodina O., Mytrofanov O., Chehlatonieva A. Equity capital: approaches to definition, classification and its structure // Food Industry Economics. 2019. Vol.11, Issue 2. P. 31-37. doi: 10.15673/fie.v11i2.1392

Cite as APA style citation

Markova T., Volodina O., Mytrofanov O. \& Chehlatonieva A. (2019). Equity capital: approaches to definition, classification and its structure. Food Industry Economics, 11(2), 31-37. doi: 10.15673/fie.v11i2.1392 